\title{
CONSERVATION OF A HISTORIC PANEL OIL-PAINTING COATED WITH AN ANCIENT VARNISH LAYER
}

\author{
Yosr Elsayed \\ Conservation Department, Faculty of Archaeology, Damietta University, Egypt \\ Email: yea00@du.edu.eg
}

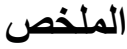

\begin{abstract}
The present research addresses the study and removal an ancient varnish layer covering the case study painting from private properties, after investigation and analysis, as well as treatment of the entire object. The study is divided into three phases. Phase 1, using some non-invasive techniques such as the MA-XRF, MA-FTIR, Xray radiography IR reflectography and UV radiation imaging, in addition to SEM-EDX, to analyse the case study, to identify the case study components and the deterioration phenomena. The results revealed a limewood support, with zincite, cerussite, red ochre, yellow ochre, cobalt blue, bone black and linseed oil in the ground and paint layers. Moreover, it was identified that the object was painted by the famous Egyptian painter Mahmoud Sa'id in the early $20^{\text {th }}$ century. Its surface suffers from a thick layer of ancient varnish. Phase 2 , the study conducted in-vitro experiments on a simulated painted model to assess the ideal technique for varnish removal. It was proven that the gel dispersion of PVAL, borax, ethanol, and water was the most efficient formula. Phase 3, Treatment of the object included varnish removal, chemical cleaning, inpainting, and consolidation.
\end{abstract}

\section{KEYWORDS}

Panel painting; MA-XRF; MA-FTIR; SEM-EDX; Varnish removal; Treatment; Conservation.
يتناول هذا البحث دراسة وإزالة طبقة ورنبش قديمة

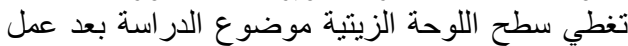

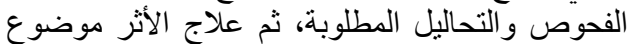

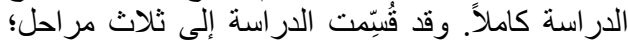

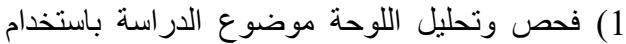

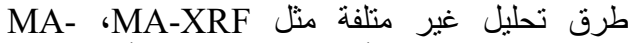

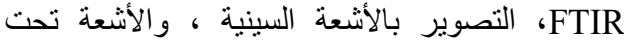

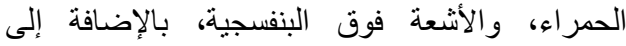

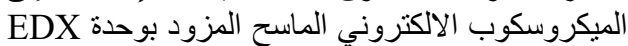

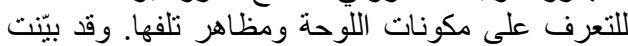

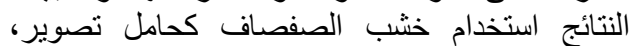

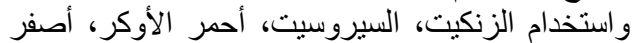
الأوكر، أزرق الكوبالت، اسود العظام وزيت بذر الكربـ الكتان في أرضية التحضير وطبقة التصوير، كما نسبت التبر اللوحة إلىى الفنان المصري الثهير محمود سعيد في مطلع

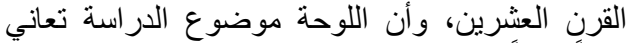

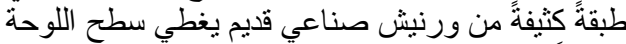

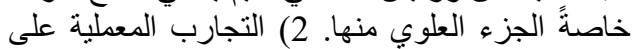

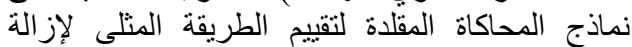

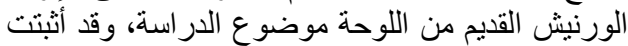

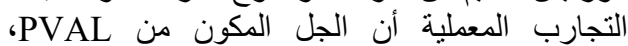
البور اكس، الايثانول والماء هو التركيبة المثلى من بين

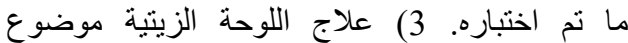

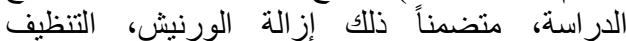
الكيميائي، تلوين المناطق المفقودة ثم التقوية.

الكلمات الدالة - الة

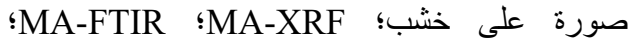
SEM-EDX

- 238 - SHEDET Issue nu. 6 (2019), pp. 238-256 


\section{INTRODUCTION}

The present research aims to study and remove an ancient varnish layer covering the case study after investigation and analysis, as well as treatment of the entire object. The case study is a panel painting from private properties. It suffers from many deterioration phenomena especially a thick layer of ancient varnish. Removal of ancient varnish thick layer is a grand risk in painting conservation. The case study is a unique one, mostly deteriorated, artistically valued, and easily movable abroad. Panel paintings have usually been implemented on wooden supports such as fir, larch, spruce, pine, maple, alder, beech, ash, walnut, poplar, cherry, pear, oak, willow, lime, and elm woods. ${ }^{1,2}$ The panel was generally prepared by scraping its surface, applying a paste of chalk and natural glue, and another instance of scraping to make it completely plane and even., After treating the faults in the wood and the preparation, the wooden support is often coated with natural glue, and then covered by a white ground layer of animal glue and white powder, such as chalk, zinc white, lead white, etc. Hereafter, this layer is covered with the paint layer consisting of different types of natural and/or synthetic pigments mixed with linseed oil, safflower oil, or other kinds of drying oils. $5,6,7,8$

In addition to the Scanning Electron Microscope with Energy Dispersive X-ray Spectroscopy unit (SEM-EDX), the most commonly used investigation and analytical technique to study different types of paintings, ${ }^{9,10}$ other non-invasive techniques were used, such as Macroscopic X-ray fluorescence (MA-XRF) ${ }^{11}$ and Macroscopic Fourier Transform Infrared (MA-FTIR) ${ }^{12}$ to identify, not only the varnish, pigments, media, and support, but also to get an elemental distribution map of the pigments and the inorganic components in the case study. Moreover, the study used X-ray radiography, UV radiation, and IR reflectography, the most commonly used techniques in imaging art objects, to identify whether the case study object contained over-paintings, shift drawings, or ancient treatments. ${ }^{13,14}$ These non-invasive techniques tend to be of higher performance instruments and are used in scanning the entire surface of the investigated object in-situ without the need to sample; indeed it is not possible to sample in some objects. $^{15,16}$

During the 1700s, abrasives, soaps, and caustic alkalis were commonly used to remove varnish, while organic solvents were the most common agents in the $19^{\text {th }}$ century. ${ }^{17}$ Since, organic solvents have been used for the removal of varnish, grime, stains, dirt,

1- Hoadley, Identification of Wood in Painting Panels, symposium at the Paul Getty, 1995.

2- Wadum, Historical Overview of Panel-Making Techniques, symposium at the Paul Getty Museum, 1995.

3- Véliz, Wooden Panels and Their Preparation, symposium at the Paul Getty Museum, 1995.

4- Costa, et al., Multi-technical analysis, J Molec Struc, 1120 (2016) 196-204.

5- Helmi and Abdel-Gwad, Scientific Study For Restoration and Conservation of Oil Paintings, 1992.

6- Costa, et al., Multi-technical analysis, J Molec Struc, 1120 (2016) 196-204.

7- Barnett et al., Colour and art, Optic Laser Tech, 38 (2005) 445-53.

8- Silva et al., Diffuse reflection FTIR, Anal Bioanal Chem., 386 (2006) 2183-2191.

9- Genestar and Pons, Earth pigments in painting, Anal Bioanal Chem, 382 (2005) 269-274.

10- Ajò et al., Ciro Ferri's frescoes, J Cult Heri, 5 (2004) 333-348.

11- Alfeld et al., Optimization of mobile scanning macro-XRF, J Anal At Spectrom, 26 (2011) 899-909.

12- Legrand et al., Macroscopic Fourier transform infrared, Analyst, 139 (2014) 2489-2498.

13- Cucci et al., Trans-illumination and trans-irradiation, J Cult Heri, 13 (2012) 83-88.

14- Emandi et al., X-Ray Radiographic Study, Int J Cons Sci, 2 (2011) 179-183.

15- Miliani et al., In situ noninvasive study of artworks, Acc Chem Res, 15 (2010) 728-38.

16- De Viguerie et al., revealing the sfumato technique, Angew Chem Int Ed., 49 (2010) 6125-6128.

17- Burnstock and Learner, Changes in the Surface Characteristics, Stud in Cons, 37 (1992) 165-184.

- 239 - DOI: $10.36816 /$ shedet.006.14 
and other deteriorating layers of oil paintings on canvas and panels. However, they sometimes cause damage to the objects if the solvent penetrates and swells within paint layers. ${ }^{18,19}$ In 1990, Wolbers introduced an innovative approach by using the gel form to reduce damages resulting from the deep penetration of liquid solvents into paint layers. Hence, with the use of gels, the solvent action is controlled upon the surface only as its suction rate into the paint layers is reduced. ${ }^{20,21}$ Many alkaline and acidic recipes to produce a gel matrix were used to remove aged varnishes applied over oil painted surfaces. The present study successfully tried a recipe of Polyvinyl Alcohol (PVAL) and borax in distilled water, ${ }^{22}$ combined with ethanol after attempts of varnish removal on simulated modern models showed improved efficiency. As a consequence of the positive results, the gel solution was applied on the case study object.

The case study object is a historical panel painting entitled "an Egyptian peasant woman" (Fig.1). It is a portrait of an Egyptian peasant woman on a wooden rectangular panel and measures $37 \times 32 \mathrm{~cm}(27 \times 22 \times 0.75 \mathrm{~cm}$ frameless size $)$. It is an object from a private collection of an Egyptian antiques' collector, painted using oil painting on a white ground layer upon a thin wooden panel $(0.75 \mathrm{~cm}$ thickness $)$. The scene depicts the Egyptian peasant woman: the brownish skin, the black eyes, the thick eyebrows, the wide-ringed ears, the covered head with a black and big scarf, the very dark blue outer clothes upon colored one, etc. Moreover, the background is yellow colored (symbol of dessert) and little green and blue colors (symbol of Nile and greens).

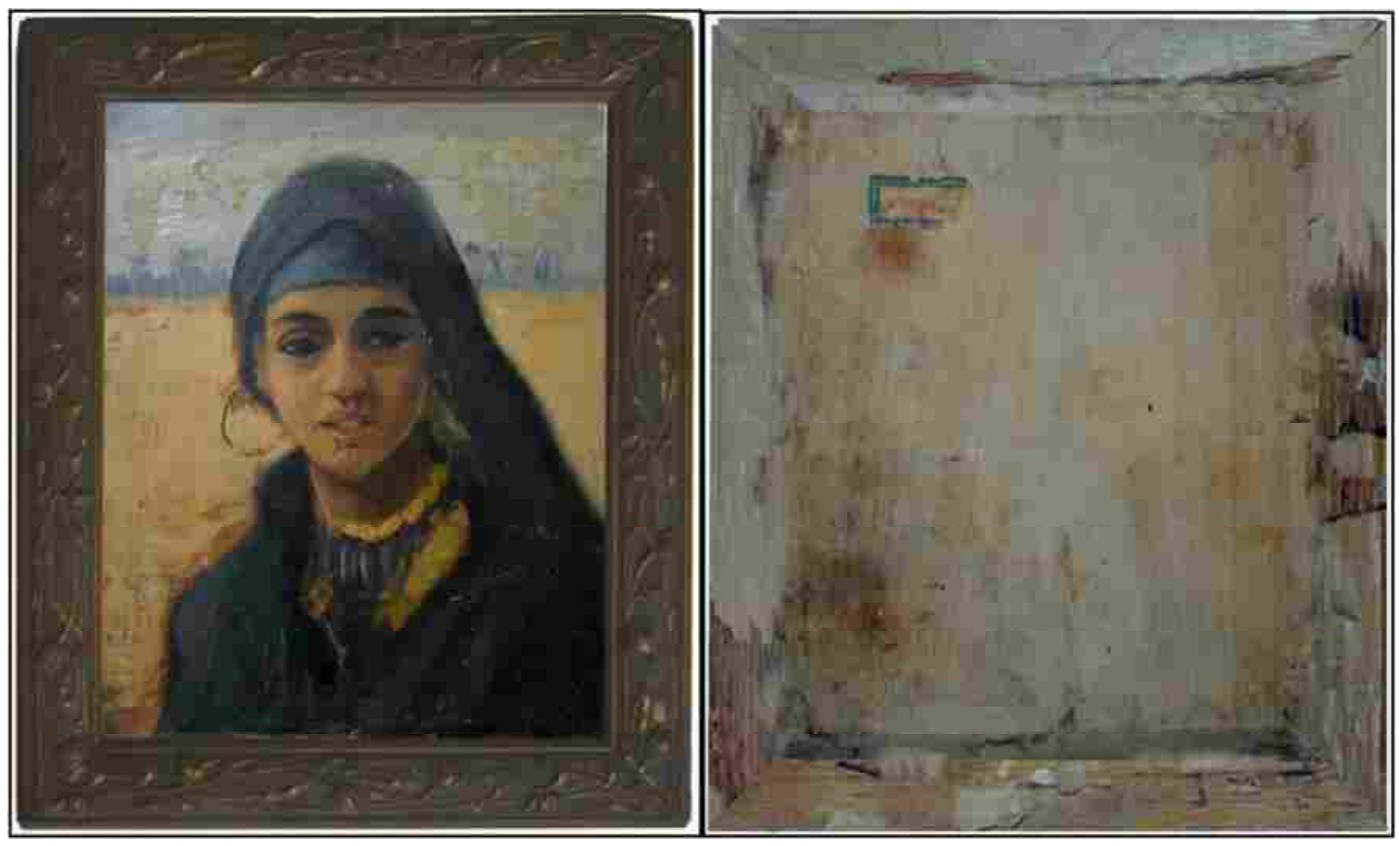

Fig.1. Obverse and Reverse of the case study panel painting "An Egyptian Peasant Woman"

No signature, nor date upon the object indicate the painter. To date this painting, the present study adopted four means; 1) the results of upcoming investigations and analytical techniques applied to the case study, 2) literature focusing on oil painting in

18- Phenix, The Swelling of Artist's Paints, JAIC, 41 (2002) 43-60.

19- Galatis et al., An Investigation of the Selective Removal, e-Preservation Science, 9 (2012) 72-8.

20- Wolbers, Cleaning Painted Surfaces, London, 2003.

21- Carretti et al., A new class of gels for the conservation, J of Cult Heri, 9 (2008) 386-393.

22- Emiliano et al., A New Family of High Viscosity, J Cult Heri, 11, 4 (2010) 373-380

- 240 - Conservation Of A Historic Panel Oil-painting Coated By An Ancient Varnish Layer 
Egypt during the $20^{\text {th }}$ century, 3) visiting some Egyptian museums displaying oil paintings, and 4) private discussions with professional painters and academics. They all suggest that it was produced in the early $20^{\text {th }}$ century, perhaps around 1920 , by Mahmoud Sa'id (1897-1964), the most famous painter dating to the $20^{\text {th }}$ century and the leader of the Modern school of painting in Egypt. It suffers from some deterioration, especially the thick ancient yellowish varnish covering the painted surface (Fig.2a), as well as missing patches of paint (Fig.2b), stains and black spots (Fig.2c), scratches (Fig.2d), and its wooden verso is completely stained (Fig.1).

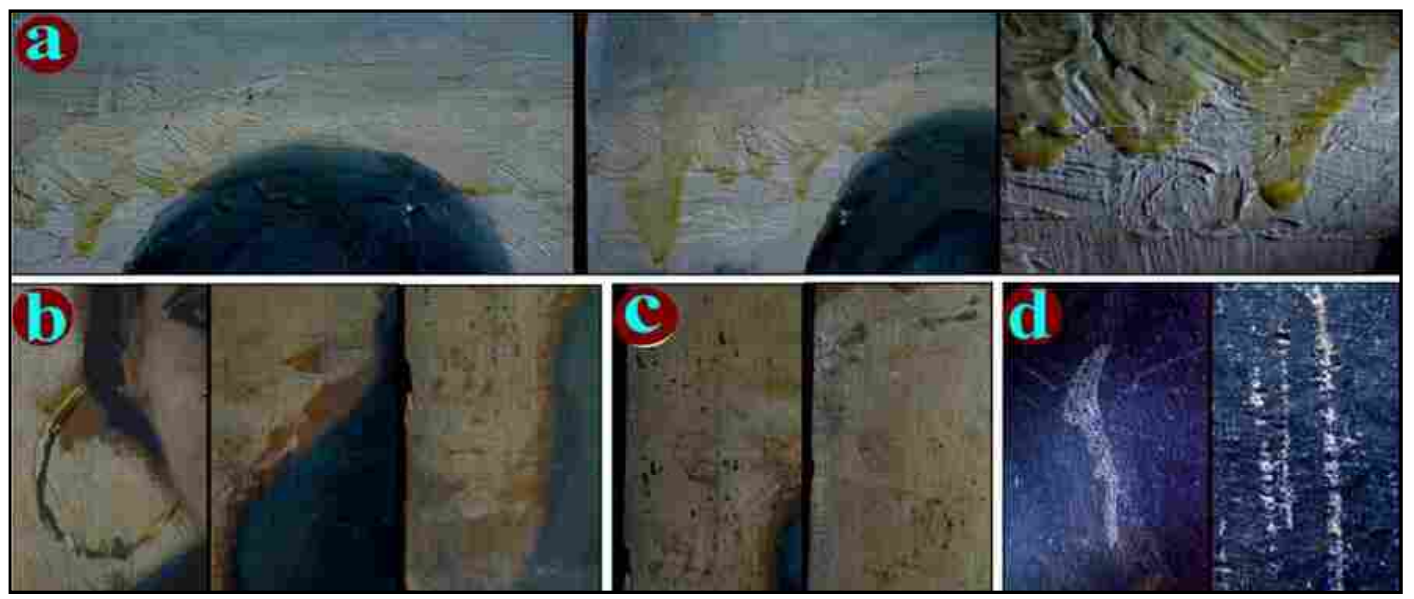

Fig.2. Enlargements of deterioration, a. ancient yellowish varnish layer, b. missing patches of paint, c. stains and black spots, d. scratches

Because it is an object from a private collection, it was possible to transport the object abroad to be investigated by non-invasive instruments, which are not available in Egypt. Indeed, if it had been kept in an Egyptian museum, it would have been impossible to transport it away from it.

The ancient varnish layer covers the entire surface of the object and a concentration is seen in the upper part. Due to its own structure and properties, the synthetic varnish, adhered well to the object surface, it was difficult to overcome this issue. The in-vitro experimental part of this study focuses on the removal of a synthetic varnish layer from simulated oil-painted panels after thermal accelerated aging. after identifying the components of the case study using different investigations and analytical techniques.

\section{MATERIALS AND METHODS}

\section{Macro X-ray fluorescence (MA-XRF)}

The study used the MA-XRF scanning system (M6 JetStream, Bruker Nano GmbH, Berlin, Germany) in the Centre for Modern Interdisciplinary Technologies (ICNT), Nicolaus Copernicus University in Torun, Poland. The measuring head consists of an Xray tube with a rhodium target. 5 filters mounted in a motorized filter wheel can are used to modify the spectral range of radiation emitted from the X-ray tube.

The configuration used in this study is as follows; an X-ray tube at $50 \mathrm{kV}$, an anode current of $600 \mu \mathrm{A}$, no filter, and a $30 \mathrm{~mm}^{2} \mathrm{SDD}$ with zirconium window. A range of $\mathrm{X}$ ray energy from $0.35 \mathrm{keV}$ to $40 \mathrm{keV}$ was covered. The most important and effective data were obtained from $\sim 2 \mathrm{keV}$ to $\sim 18 \mathrm{keV}$. The scan was carried out in an atmosphere of 1055 mbar which allows the detection of elements from their K-lines and heavier elements from their L-lines. The pixel size was $650 \mu \mathrm{m}$ and the pixel time was

- 241 - DOI: 10.36816/shedet.006.14 
$35 \mathrm{~ms} /$ pixel during data collection of the entire object, which lasted for 1 hour and 16 minutes.

\section{Macro Fourier transform infrared (MA-FTIR)}

MA-FTIR is commonly used to identify the binding media and the pigments in historical objects. It is one of the most famous cutting-edge and non-invasive techniques in the analysis of heritage materials. The study used Hyperion 1000 FTIR Microscope, Vertex 70V, Bruker Optic, reflection mode, objective 20×, the number of scans 512, wave number $4000-400 \mathrm{~cm}^{-1}$. Five points at the surface of the object were carefully selected during the analysis. They were in the outer parts covered with the wooden frame where there is no varnish, or at least, less. The analysis focused on single-colour areas to identify both the pigment and the oil media.

\section{X-Ray, UV and IR scientific imaging}

The case study painting was investigated by X-ray Radiography to give insight into the artist's materials and painting techniques, and to reveal the probably covered data under the paint layer or on the wood panel. The study used a digital X-ray camera system including an Orange 1040HF Portable X-ray source (DIX-RAY Polska Sp. zoo, Cisek, Poland) and a wireless Examion Dix-Ray ${ }^{\circledR}$ Flexible ${ }^{\circledR}$ X-ray detector (FPS Dix-Ray ${ }^{\circledR}$ (DIX-RAY Polska Sp. zoo, Cisek, Poland). The exposure voltage was $40 \mathrm{kV}$, while the intensity was $40 \mathrm{~mA}$.

The case study was also photographed in different wavelengths of electromagnetic radiation: Visible light (VIS), Near-Infrared (NIR) and Ultraviolet (UV). The UV induced imaging was implemented using four fluorescent tubes of 40W (General Electric F40T12 Black Light Blue, New York, USA) and emitting radiation of a wavelength of $368 \mathrm{~nm}$. The UV images were captured by Canon ${ }^{\circledR}$ EOS Canon EOS 5D Mark III camera, focal length of $100 \mathrm{~mm}, \mathrm{f} / 6.3$, exposure time of 30s, ISO 100, no flash. The VIS images were captured by Canon ${ }^{\circledR}$ EOS Canon EOS 5D Mark III camera, focal length of $100 \mathrm{~mm} \mathrm{f} / 10$, exposure time of $0.5 \mathrm{~s}$, ISO 100, no flash. The IR induced imaging was implemented under a wavelength of 830-1000 nm; images were captured by FUJIFILM IS pro camera, focal length of $60 \mathrm{~mm}, \mathrm{f} / 16$, exposure time of $0.62 \mathrm{~s}$, ISO 100 , no flash.

\section{Scanning Electron Microscope with EDX (SEM-EDX)}

The Scanning Electron Microscope with EDX (Jeol/EO, Japan, Jsm, 6510, ACCEL_VOLT 20, MAG 4300, SIGNAL SEI, low vacuum mode 100-120 Pa, at 15-20 $\mathrm{kV}$ ) in the Electron Microscopy unit of Mansoura University was used in the investigation and analysis of five micro-samples that were carefully collected from the surface and the wooden panel of the painting. This helped identify the deterioration phenomena, as well as analyse the overall chemical composition. Moreover, SEM was used to scan the modern simulated painting samples during the in-vitro experiments for varnish removal.

\section{RESULTS AND DISCUSSION}

\section{MA-XRF}

The case study was scanned by MA-XRF. The included maps (Fig.3) disclosed the elemental distribution of high-intensity elements in the painting. Different spectra (Fig.4) revealed the presence and intensity of calcium $(\mathrm{Ca})$, barium $(\mathrm{Ba})$, chromium

- 242 - Conservation Of A Historic Panel Oil-painting Coated By An Ancient Varnish Layer 
$(\mathrm{Cr})$, iron $(\mathrm{Fe})$, cobalt $(\mathrm{Co})$, copper $(\mathrm{Cu})$, zinc $(\mathrm{Zn})$, mercury $(\mathrm{Hg})$, and lead $(\mathrm{Pb})$. Iron, Zinc, and Lead show stronger signals than the others. Iron may refer to the yellow and reddish-brown iron oxides $\left(\mathrm{Fe}_{2} \mathrm{O}_{3} \cdot \mathrm{H}_{2} \mathrm{O}\right.$ and $\left.\mathrm{Fe}_{2} \mathrm{O}_{3}\right)$, both commonly used as colouring agents for yellow and reddish-brown colours in different shadows. ${ }^{23,24}$ Zinc may refer to zincite (zinc oxide $\mathrm{ZnO}$ ) in white color, and Lead to the presence of either cerussite (lead carbonate $\mathrm{Pb}_{3} \mathrm{CO}_{3}$ ) or hydrocerussite (hydrate lead carbonate $\mathrm{Pb}_{3}\left(\mathrm{CO}_{3}\right)_{2}(\mathrm{OH})_{2}$ ), both used either as a white colouring pigment for lightening the dark shadow or mixed with a bonding media as a white base layer. ${ }^{25,26}$

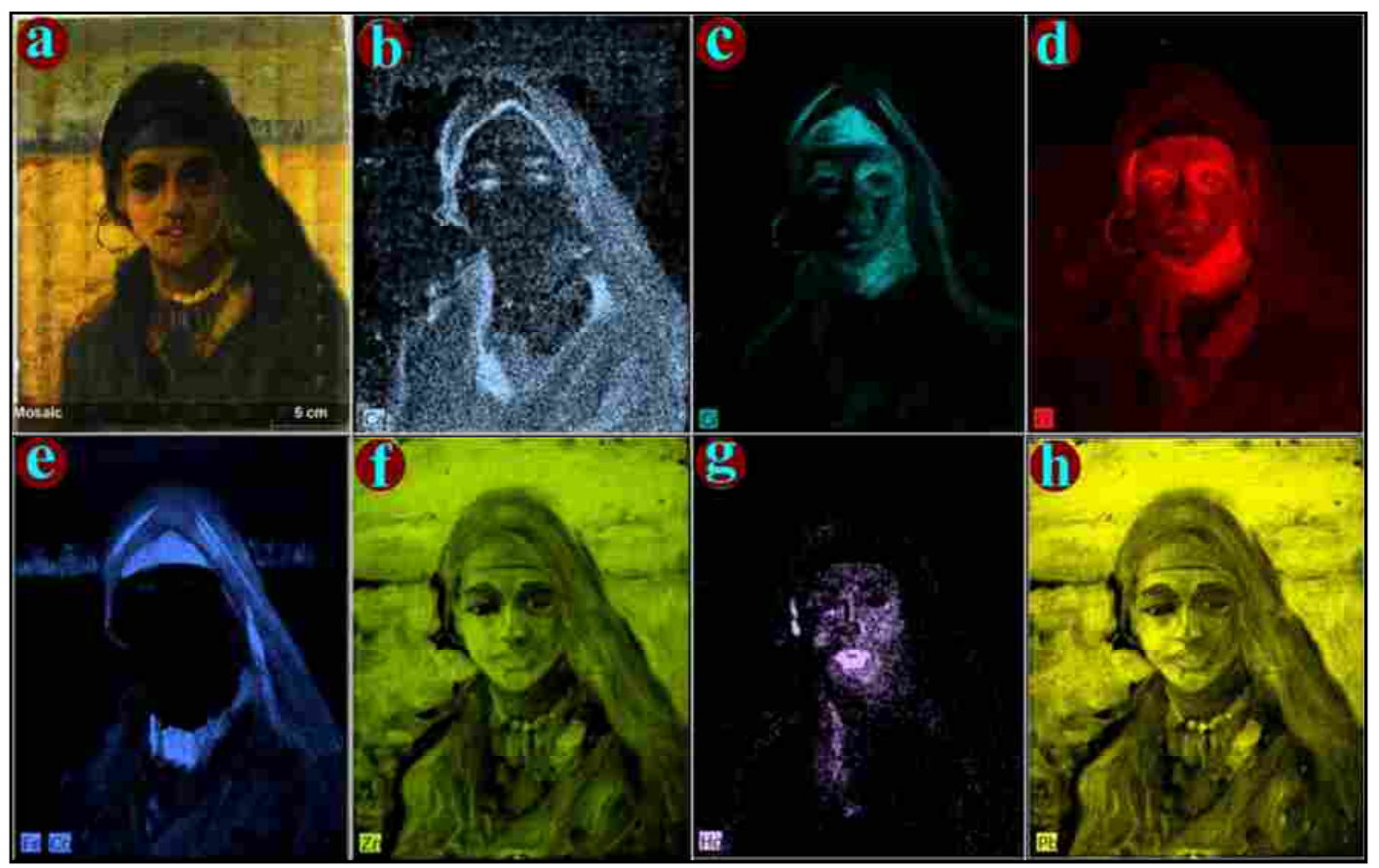

Fig.3. Elemental distribution maps of the detected elements, a. (mosaic image), b. (Ca), c. (Cr), d. (Fe), e. (Co), f. $(\mathrm{Zn})$, g. $(\mathrm{Hg})$, h. $(\mathrm{Pb})$ in the case study painting

The presence of $\mathrm{Ca}$ in the dark blue areas in addition to other expected undetectable elements, such as $\mathrm{C}, \mathrm{O}, \mathrm{H}$, and $\mathrm{P}$ may indicate using bone black (hydroxyapatite "calcium phosphate" and carbon $\left.\mathrm{Ca}_{5}(\mathrm{OH})\left(\mathrm{PO}_{4}\right)_{3} \mathrm{C}\right) .{ }^{27,28}$ The presence of Co in the same dark blue areas with $\mathrm{Ca}$ suggests the use of cobalt blue pigment (cobalt aluminate $\mathrm{CoAl}_{2} \mathrm{O}_{4}$ ), but $\mathrm{Al}$ isn't easily detectable. Generally, cobalt blue was used as a blue coloring material ${ }^{29,30}$ Clearly, bone black and cobalt blue were combined to obtain the dark blue areas in the case study object.

The results proved the weak presence of $\mathrm{Cr}$ and $\mathrm{Hg}$ in small areas, indicated in red. This $\mathrm{Cr}$, in addition to the strong signal of $\mathrm{Pb}$, may refer to chrome red (lead chromate $\left.\mathrm{PbCrO}_{4}\right) . \mathrm{Hg}$, in addition to probably undetectable sulphur $\mathrm{S}$, may refer to vermilion red

23- Alfeld et al., Revealing hidden paint layers, J Anal At Spect, 28, 1 (2013) 28-40.

24- Clark, Pigment Identification by Spectroscopic Means, Comptes Rendus - Chimie, 5, 1 (2002) 7-20.

25- Costa et al., Multi-technical analysis, J Molecu Struc, 1120 (2016)196-204

26- Elsayed and Shabana, The Effect of Some Essential Oils, Med Arch and Aarchaeom, 3 (2018) 71-87

27- Winter and Fitzhugh, Pigments based on carbon, National Gallery of Art, 2007.

28- Campos et al., X-ray fluorescence and imaging analyses, Rad Phy and Chem, 95 (2014) 362-367.

29- Spring et al., Quantitative energy dispersive X-ray analysis, London, 2012.

30- Campos et al., X-ray fluorescence and imaging analyses, Rad Phy and Chem, 95 (2014) 362-367.

- 243 - $\quad$ DOI: 10.36816/shedet.006.14 
(mercury sulfide $\mathrm{HgS}$ ). ${ }^{31,32}$ They were both used for reds, especially the lady's mouth and the surrounding area. $\mathrm{Hg}$ is highly concentrated on the lady's lips. In other words, this area might be over painted with other colors upon a red painted area. Sometimes, $\mathrm{HgS}$ is mixed with $\mathrm{Fe}_{2} \mathrm{O}_{3}$ to be used as a two in one red coloring pigment. ${ }^{33,34}$ The small signals of $\mathrm{Cu}$ and $\mathrm{Ba}$ may refer to some impurities either in the ground layer or in the coloring pigments. Due to some shortage in MA-XRF, some elements, such as $\mathrm{C}, \mathrm{O}, \mathrm{S}$, $\mathrm{P}, \mathrm{Mg}, \mathrm{Si}$, and $\mathrm{Al}$ may be undetectable. ${ }^{35,36}$

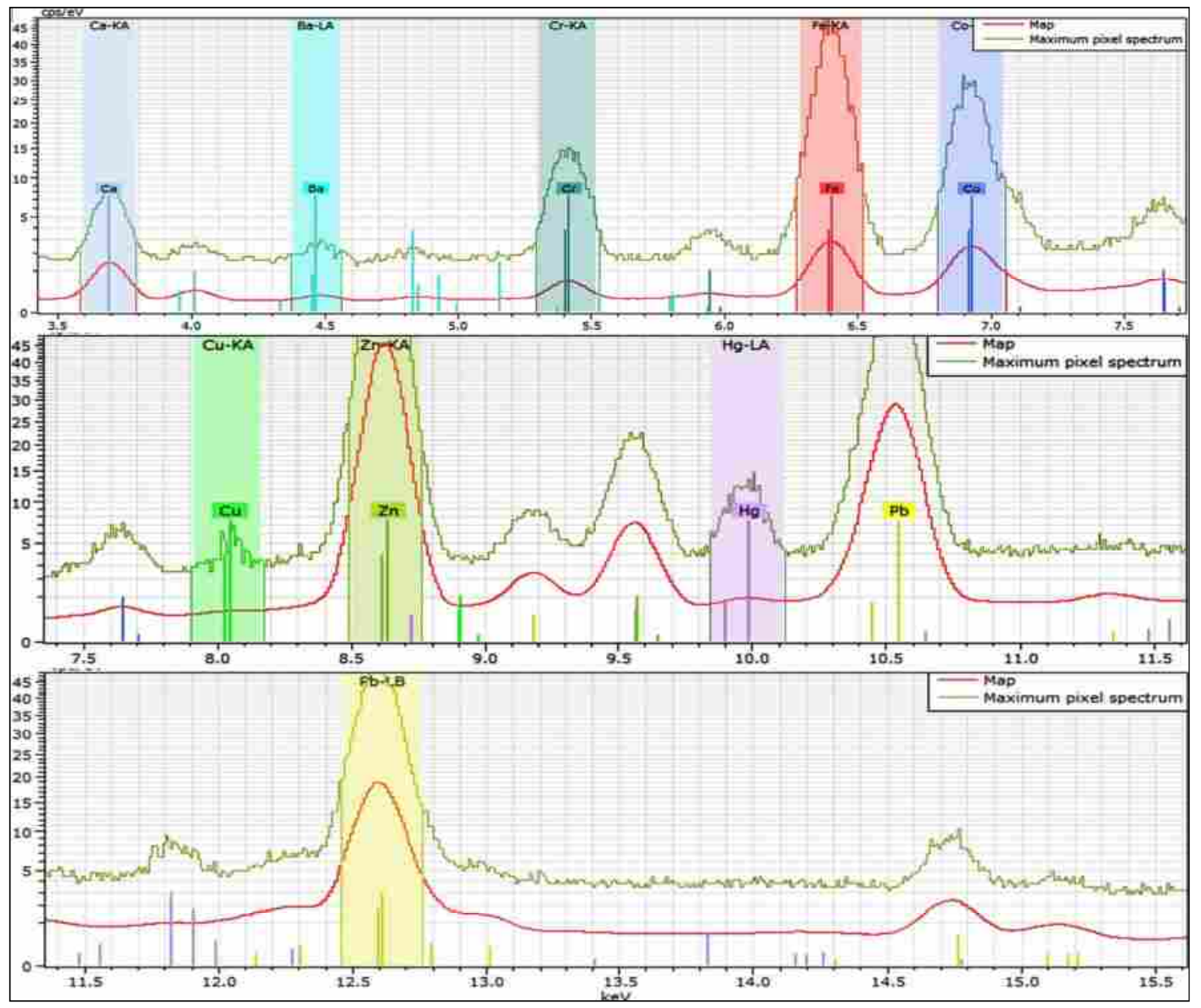

Fig.4, MA-XRF spectra of the case study object revealing the presence of Calcium (Ca-K $\alpha$ ), Chromium $(\mathrm{Cr}-\mathrm{K} \alpha)$, Iron $(\mathrm{Fe}-\mathrm{K} \alpha)$, Cobalt $(\mathrm{Co}-\mathrm{K} \alpha)$, Zinc $(\mathrm{Zn}-\mathrm{K} \alpha)$, Lead $(\mathrm{Pb}-\mathrm{L} \alpha, \mathrm{L} \beta)$, and Mercury $(\mathrm{Hg}-\mathrm{L} \alpha)$, as well as weak signals of Barium (Ba-L $\alpha)$ and Copper $(\mathrm{Cu}-\mathrm{K} \alpha)$

\section{MA-FTIR}

The results of the investigated samples by MA-FTIR in ATR mode (Fig.5), with the $\mathrm{C}=\mathrm{O}$ stretching band appearing at $\sim 1695 \mathrm{~cm}^{-1}$ and $\sim 1730 \mathrm{~cm}^{-1}$, revealed that linseed oil was the binding media. In addition, the bands appearing at $\sim 1242 \mathrm{~cm}^{-1}, \sim 1171$ $\mathrm{cm}^{-1}, \sim 1090 \mathrm{~cm}^{-1}$, and $\sim 715 \mathrm{~cm}^{-1}$ were also assigned to linseed oil ${ }^{37,38}$. The varnish

31- Campos et al., X-ray fluorescence and imaging, Rad Phy and Chem, 95 (2014) 362-367.

32- De Keyser et al., Jan Davidsz. de Heem, Herit Sci (2017) 5:38.

33- Helwing, Iron oxide pigments, Washington, 4 (2007) 39-109.

34- Šefců et al., Investigation of the panel painting, Appl Radiat Isot, 95 (2015) 8-12.

35- Targowski et al., The Application of Macro-X-Ray Fluorescence, Stud in Cons, 60 (2015) 167-177.

36- Alfeld et al., Optimization of mobile scanning macro-XRF, J Anal At Spectrom, 26 (2011) 899-909.

37- Kopecká and Svobodová, Methodology for infrared spectroscopy, Heri Sci (2014) 2:22.

- 244 - Conservation Of A Historic Panel Oil-painting Coated By An Ancient Varnish Layer 
layer was suggested to be a synthetic polyurethane, $\mathrm{N}-\mathrm{H}$ was at $\sim 3330-3350 \mathrm{~cm}^{-1}$, O$\mathrm{H}$ stretching band was at $\sim 3400 \mathrm{~cm}^{-1}$, the peaks at 2860 and $2920 \mathrm{~cm}^{-1}$ were the frequencies of stretching of $\mathrm{CH} 2$ and $\mathrm{CH} 3$, the peak at $2360 \mathrm{~cm}^{-1}$ were probably caused by $-\mathrm{NCO}$ group, and $\sim 1740 \mathrm{~cm}^{-1}$ was the $\mathrm{C}=\mathrm{O}$ stretching frequency. ${ }^{39,40}$

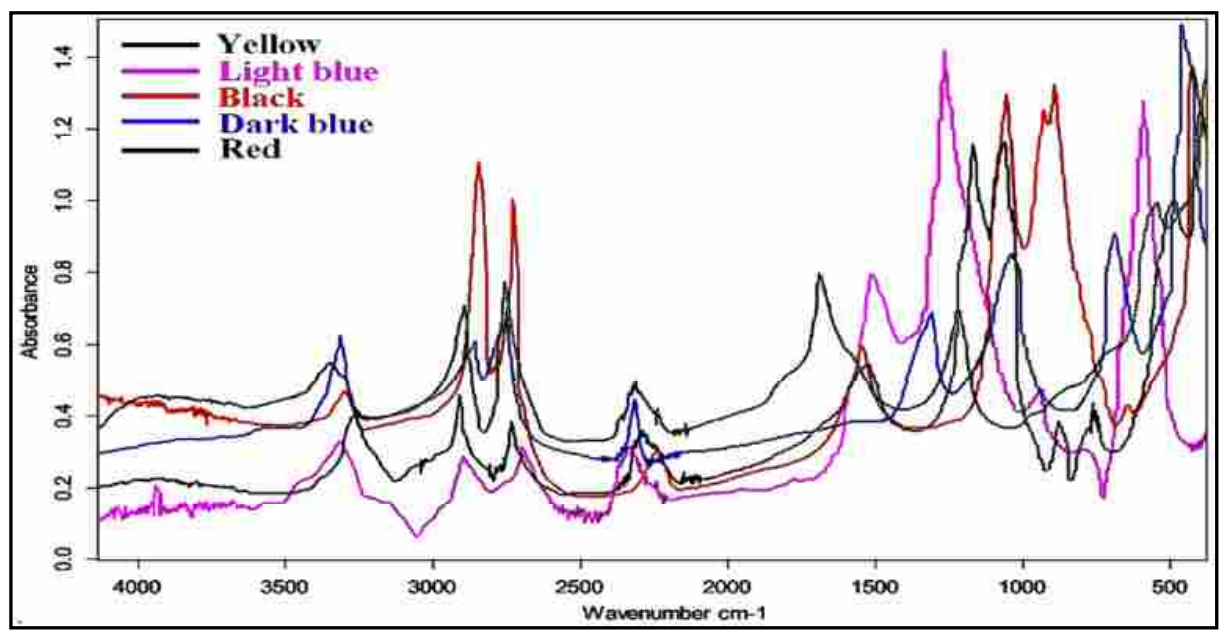

Fig.5, MA-FTIR spectra of the investigated points in the case study object

The interpretation of the spectra relevant to the used pigments revealed that the reddish brown sample was the red ochre (iron oxide $\mathrm{Fe}_{2} \mathrm{O}_{3}$ ) at $\sim 455$ and $\sim 545 \mathrm{~cm}^{-1}$, , while the yellow ochre (iron oxide $\mathrm{Fe}_{2} \mathrm{O}_{3} \cdot \mathrm{H}_{2} \mathrm{O}$ ) characterized the absorption bands at $\sim 3436$, $\sim 3150, \sim 900, \sim 800, \sim 535$ and $\sim 470 \mathrm{~cm}^{-1}$. ${ }^{42}$ The blue sample contained cobalt blue (cobalt aluminate $\mathrm{CoAl}_{2} \mathrm{O}_{4}$ ) and could be identified at $\sim 1200$ to $\sim 1500^{-1}{ }^{43,44}$ The black sample was suggested to be the bone black $\left(\mathrm{Ca}_{5}(\mathrm{OH})\left(\mathrm{PO}_{4}\right)_{3} \mathrm{C}\right), v_{3}\left(\mathrm{PO}_{4}\right)^{3-}$ was shown at $\sim 1090 \mathrm{~cm}^{-1}, v_{1}\left(\mathrm{PO}_{4}\right)^{3-}$ was shown at $\sim 895 \mathrm{~cm}^{-1}$ and $\sim 960 \mathrm{~cm}^{-1}, v_{4}\left(\mathrm{PO}_{4}\right)^{3-}$ was shown at $\sim 630 \mathrm{~cm}^{-1}$, and $v_{2}\left(\mathrm{PO}_{4}\right)^{3-}$ was shown at $\sim 460 \mathrm{~cm}^{-1} \cdot{ }^{45,46}$ zinc white $(\mathrm{ZnO})$ could be obtained through the $\mathrm{Zn}-\mathrm{O}$ stretching mode at $\sim 500 \mathrm{~cm}^{-1}$, and the asymmetric $\mathrm{COO}^{-}$, stretching mode at $\sim 1537-1560 \mathrm{~cm}^{-1}$. The distribution of zinc white $(\mathrm{ZnO})$ in the whole object could be obtained via the intense reflection FTIR band around 388, 469 and $500-517 \mathrm{~cm}^{-1}$. ${ }^{47,48}$ Based on $\mathrm{C}-\mathrm{O}$ stretching and $\mathrm{CO}_{3}{ }^{2-}$ bending vibrational bands at $\sim 1400$ and $\sim 680 \mathrm{~cm}^{-1}$, FTIR spectrum of the light blue area indicated the presence of cerussite $\left(\mathrm{Pb}_{3} \mathrm{CO}_{3}\right){ }^{49}$

\section{X-ray radiography}

Comparing the visible light image of the object (Fig.6a) to the X-ray image (Fig.6b), the $\mathrm{X}$-ray revealed that the wooden panel contained no cracks, dowels, or iron pins, and that

38- Elsayed, Identification of Oil Media in Five Canvas Paintings, J Facu of Arch 10 (2015) 60-92.

39- Yongxiang et al., Water vapour in the coatings, Progress in Organic Coatings, 45 (2002) 331-339.

40- Defeyt et al., Polyurethane coatings used in twentieth century, Heri Sci (2017) 5:11.

41- Legrand et al., Macroscopic Fourier transform infrared, Analyst, 139 (2014) 2489-2498

42- Genestar and Pons, Earth pigments in painting, Anal Bioanal Chem, 382 (2005) 269-274.

43- Delaney et al., Visible and infrared imaging, Appl Spectrosc, 64 (2010) 584-94.

44- Genestar and Pons, Earth pigments in painting, Anal Bioanal Chem, 382 (2005) 269-274.

45- Daveri at al., The bone black pigment identification, J Anal Meth in Chem, 8 (2018) 1-8.

46- Miliani et al., Reflection infrared spectroscopy, Appl Phys A, 106 (2012) 295-307.

47- Robinet and Corbeil, The characterization of metal soaps, Stud in Cons, 48 (2003) 23-40.

48- Vahur et al., ATR-FT-IR spectral collection, Anal Bioanal Chem, 408 (2016) 3373-3379.

49- Ferri, OM - SEM/EDS - $\mu$ FT -IR, Imaging \& Microscopy, 24 (2015).

- 245 - $\quad$ DOI: 10.36816/shedet.006.14 
the wood used was a single panel. The wooden structure seemed uniform, and the fibres were not detected. This might be attributed to using a panel from limewood. The image revealed that the painter used a small brush in depicting the foreground of the scene (the lady's face and clothes) while a large brush was used to execute the background (the sky and the surrounding yellowish desert). The lighter brushstrokes and lighter spots in the background and the lady's right cheek suggested using lead carbonate, which can attenuate the X-rays because of the high atomic number of lead. This result coincides with the MA-XRF and EDX results, which confirmed the presence of lead. No corrections, changes, hidden tracks, nor preliminary drawings were found. ${ }^{50,51}$

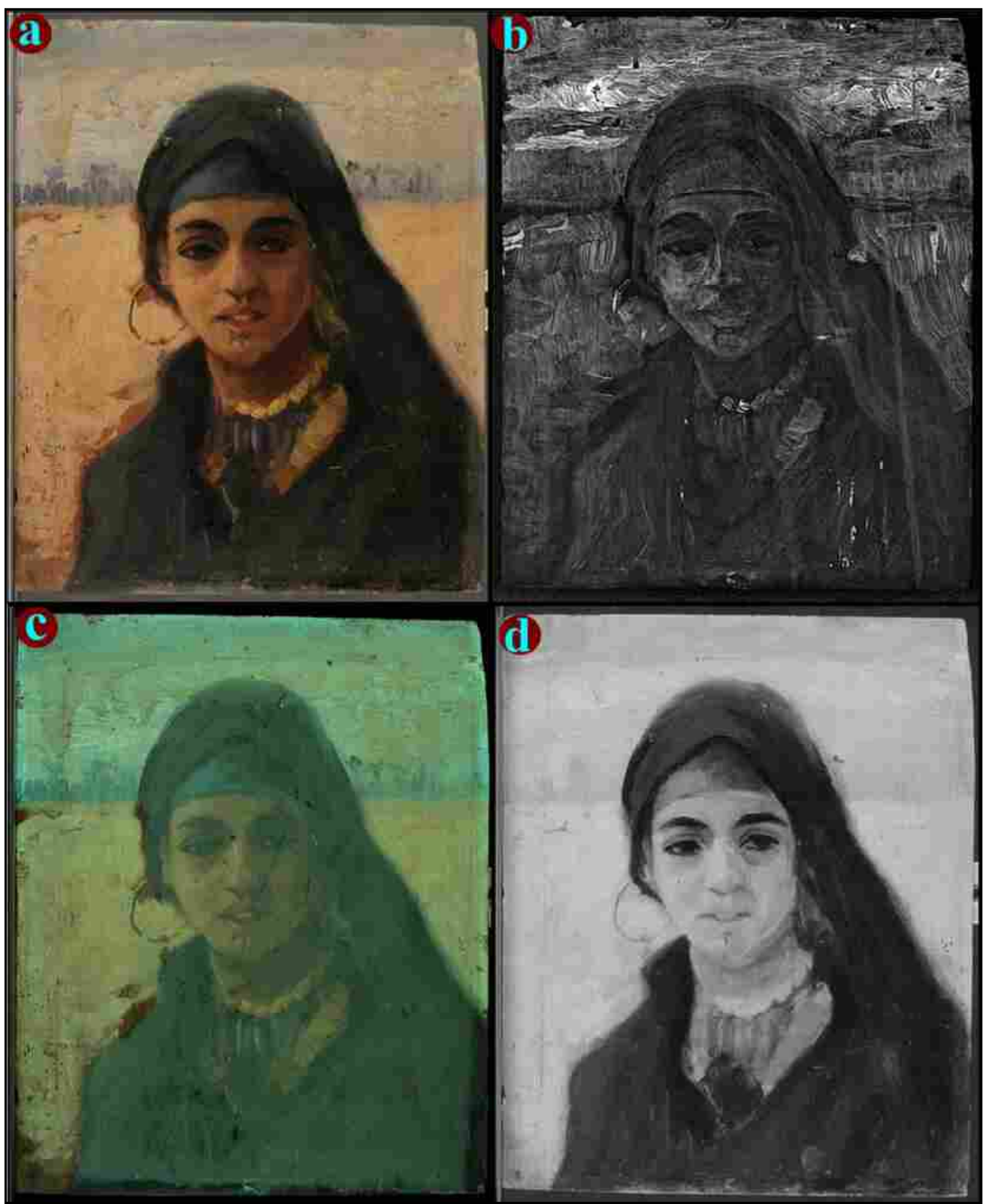

Fig.6, Scientific imaging of the object by a. visible light, b. X-ray, c. UV, IR

50- Šefců et al., Investigation of the panel painting, Appl Radiat Isot, 95 (2015) 8-12.

51- Cucci et al., Trans-illumination and trans-irradiation, J Cult Heri, 13 (2012) 83-88.

- 246 - Conservation Of A Historic Panel Oil-painting Coated By An Ancient Varnish Layer 


\section{UV radiation}

The UV radiation image (Fig.6c) revealed no notable data relevant to the structural composition of the case study. It generally featured light bluish green emission generally caused by zinc oxide. ${ }^{52}$ Lead white emits a bluish-pale light, vermillion emits a purple-violet light, and iron oxides become darker under UV light. ${ }^{53}$ Variations of emission color and density were the evidence of interventions performed at different times. $^{54}$

\section{IR Reflectography}

The IR image (Fig.6d) showed no notable shifts or corrections in the drawing contours. Thus, the object had either no preparatory drawings or an undetectable one, due to some thick paint layers, which absorbed the IR radiation and hindered its penetration underneath. IR reflectography is generally an insufficient technique to definitively decide if preliminary drawings are missing. In addition, there were no dense hatching or darker spots, suggesting that there were no ancient restoration works or retouching. ${ }_{55,56}$

\section{SEM-EDX}

The SEM micrographs showed the thick and stiff varnish layer upon the paint surface, which almost covered the paint details in the upper part of the object (Fig.7a), and the heterogeneousness of the varnish layer, which appeared as a mass in some spots but disappeared in others in the middle part (Fig.7b). The micrographs of the lower part revealed the presence of stains, dirt spots and cracks in the absence of varnish (Fig.7c). The micrograph of the wooden panel of the case study painting in comparison to the SEM micrographs of the reference natural wood ${ }^{57}$ suggested that the type of wood used is limewood (Fig.7d), commonly used in paintings since the Middle Ages. ${ }^{58}$ The results of elemental analysis of the EDX unit and the expected used pigments are summarized in Table 1.
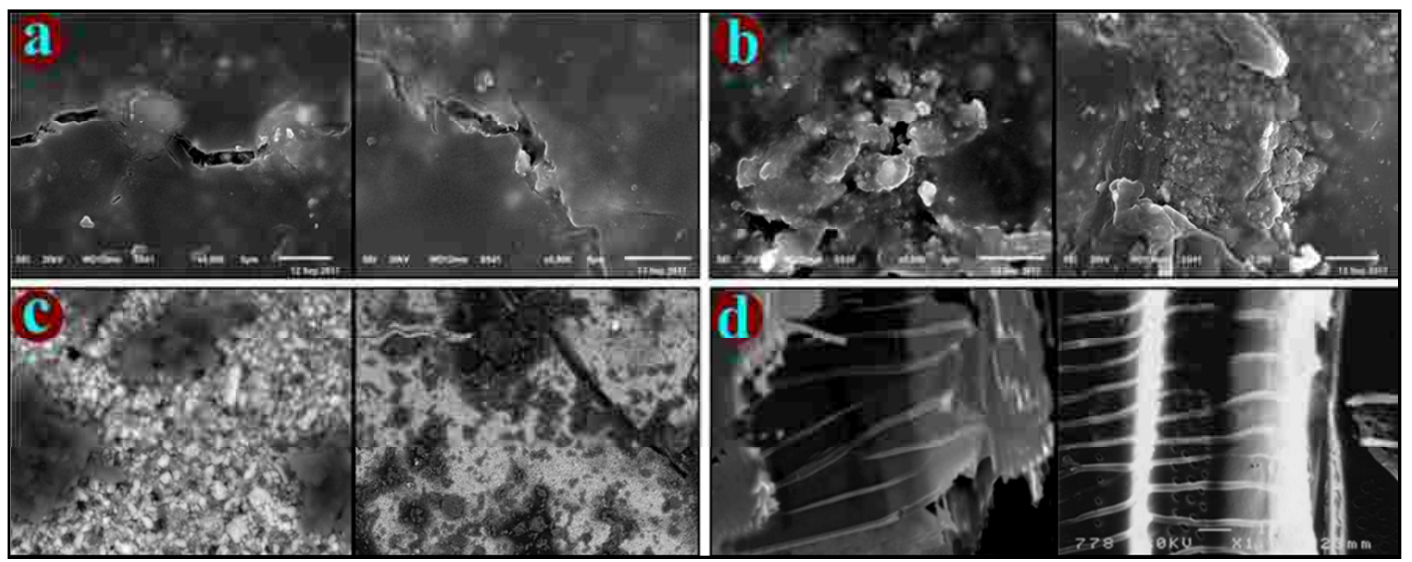

Fig.7. SEM micrographs of the investigated samples: a. the thick and stiff varnish; b. the heterogeneous varnish; c. stains, dirt spots, and cracks; d. the reference samples of limewood

52- Shabunya-Klyachkovskaya et al., A multi-analytical study, J Cult Heri, 28 (2017) 158-163. 53- Samoilescu et al., A comparative study of two icons, J Cult Heri, 27 (2017) 175-180.

54- Shabunya-Klyachkovskaya et al., A multi-analytical study, J Cult Heri, 28 (2017) 158-163.

55- Cucci et al., Trans-illumination and trans-irradiation, J Cult Heri, 13 (2012) 83-88.

56- Marín and Garcia, The sixteenth century panel, J Cult Heri, 29 (2018) 160-167.

57- Popescu et al., Microscopic study of lime wood, Cellulose Chem Tech, 4 (2011) 565-569.

58- Wadum, Historical Overview of Panel-Making Techniques, the Paul Getty Museum, 1995.

- 247 - DOI: 10.36816/shedet.006.14 
Table 1: EDX results of the investigated micro-samples and a suggestion of used materials

\begin{tabular}{|c|c|c|}
\hline Sample & Detected elements & Suggestion of used materials \\
\hline $\begin{array}{l}\text { Reddish } \\
\text { brown }\end{array}$ & $\begin{array}{l}\mathrm{C}, \mathrm{O}, \mathrm{Mg}, \mathrm{Si}, \mathrm{P}, \mathrm{S}, \mathrm{K}, \mathrm{Ca}, \mathrm{Cr} \\
\mathrm{Fe}, \mathrm{Zn}, \mathrm{Ba} \text {, and } \mathrm{Pb}\end{array}$ & $\begin{array}{l}\text { Red ochre }\left(\mathrm{Fe}_{2} \mathrm{O}_{3}\right) \text { - zinc white }(\mathrm{ZnO}) \text { - hydrocerussite } \\
\left(\mathrm{Pb}_{3}\left(\mathrm{CO}_{3}\right)_{2}(\mathrm{OH})_{2}\right) \text { - quartz }\left(\mathrm{SiO}_{2}\right) \text { - barite }\left(\mathrm{BaSO}_{4}\right)\end{array}$ \\
\hline Yellow & $\begin{array}{l}\mathrm{C}, \mathrm{O}, \mathrm{Al}, \mathrm{Si}, \mathrm{Ca}, \mathrm{Cr}, \mathrm{Fe}, \mathrm{Zn} \text {, and } \\
\mathrm{Pb}\end{array}$ & $\begin{array}{l}\text { Yellow ochre }\left(\mathrm{Fe}_{2} \mathrm{O}_{3} \cdot \mathrm{H}_{2} \mathrm{O}\right) \text { - hydrocerussite } \\
\left(\mathrm{Pb}_{3}\left(\mathrm{CO}_{3}\right)_{2}(\mathrm{OH})_{2}\right) \text { - zinc white }(\mathrm{ZnO})\end{array}$ \\
\hline Blue & $\begin{array}{l}\mathrm{C}, \mathrm{O}, \mathrm{Mg}, \mathrm{Al}, \mathrm{P}, \mathrm{S}, \mathrm{Cl}, \mathrm{K}, \mathrm{Ca} \\
\mathrm{Cr}, \mathrm{Fe}, \mathrm{Co}, \mathrm{Zn}, \mathrm{Sr} \text {, and } \mathrm{Ba}\end{array}$ & $\begin{array}{l}\text { Cobalt blue }\left(\mathrm{CoAl}_{2} \mathrm{O}_{4}\right) \text { - zincite }(\mathrm{ZnO}) \text { - hydrocerussite } \\
\left(\mathrm{Pb}_{3}\left(\mathrm{CO}_{3}\right)_{2}(\mathrm{OH})_{2}\right) \text { - Barite }\left(\mathrm{BaSO}_{4}\right)\end{array}$ \\
\hline black & $\begin{array}{l}\mathrm{C}, \mathrm{O}, \mathrm{Mg}, \mathrm{Al}, \mathrm{Si}, \mathrm{P}, \mathrm{Ca}, \mathrm{Cr}, \mathrm{Fe} \\
\mathrm{Zn} \text {, and } \mathrm{Pb}\end{array}$ & $\begin{array}{l}\text { Bone black }\left(\mathrm{C}, \mathrm{Ca}_{5}(\mathrm{OH})\left(\mathrm{PO}_{4}\right)_{3}\right) \text { - zinc white }(\mathrm{ZnO})- \\
\text { hydrocerussite }\left(\mathrm{Pb}_{3}\left(\mathrm{CO}_{3}\right)_{2}(\mathrm{OH})_{2}\right)\end{array}$ \\
\hline
\end{tabular}

\section{EXPERIMENTS IN VARNISH REMOVAL}

The ancient varnish layer covering the whole object, especially its upper part, was the main deterioration phenomenon in the case study painting. It was thick, yellowish, dark, and preventing vision. Thus, the experimental part of the present study focuses on the removal of modern varnish from simulated painted panels using suitable materials and methods to identify the most effective way. Once this technique was identified, it was applied to remove the ancient varnish layer in this painting. The experiment was conducted according to the following steps:

\section{Preparation of the simulated paintings}

The simulated paintings were prepared according to the technical specificities resulting from the analysis of the case study. The well-known techniques of oil painting panelmaking were followed $;^{59,60,61,62}$ a freshly prepared and suitable modern limewood panel was used, then the surface coated with a white ground layer composed of animal glue and zinc white (Alwan store, Giza, Egypt). After drying, the white base layer was oilpainted with two separate colours, yellow made of yellow ochre mixed with linseed oil, and light blue, made of cobalt blue, zinc white with linseed oil (Winsor \& Newton, UK). After leaving it to dry at room temperature for five days (Fig.8a), the oil-painted surface was brushed by a thick layer of fresh synthetic polyurethane varnish (JOTUN, Egypt). After five more days at room temperature, the varnish layer had dried (Fig.8b); the modern models were thermally aged at $80 \pm 2^{\circ} \mathrm{C}$ for 144 hours in an electric oven (Thermo Scientific Oven under Vacuum). It was then kept for 72 hours at room temperature before starting the experiments (Fig.8c).

\section{Removal of the varnish layer}

To eliminate the varnish layer, the study tested three recipes:

RA: Stoddard solvent (Merck). ${ }^{63,64}$ The solvent was applied on the varnish layer in the form of a poultice slightly wet with the solvent, and then put carefully upon the varnish

59- Gottsegen, A manual of painting materials and techniques, New York, 1987.

60- Véliz, Wooden Panels and Their Preparation, symposium at the Paul Getty Museum, 1995.

61- Nicolaus, and Christine, The Restoration of Paintings, Cologne: Könemann, 1999.

62- Elsayed and Shabana, The Effect of Some Essential Oils, Med Arch and Aarchaeom, 3 (2018) 71-87.

63- Sutherland, The Extraction of Soluble Components, Stud in Cons, 45, (2000) 54-62.

64- Hook, The Use of Immiscible Solvent Combinations, JAIC, 27, 2 (1988) 100-104.

- 248 - Conservation Of A Historic Panel Oil-painting Coated By An Ancient Varnish Layer 
surface for 10 minutes. After that, it was removed, and then the surface was gently cleaned using Stoddard swabs (Fig.8d).

RB: A Dispersion of PVAL (Sigma-Aldrich), Sodium tetraborate dehydrate "Borax" (Sigma-Aldrich) and distilled water. The dispersion was prepared by dissolving $0.4 \mathrm{wt} \%$ of borax in water, then $2 \mathrm{wt} \%$ of PVAL was added and dissolved by stirring and heating the mixture for 3 hours at $90^{\circ} \mathrm{C}$. The dispersion was cooled to room temperature in order to be used in the form of gel. ${ }^{65}$ It was applied upon the varnish surface for 10 minutes then removed. Later, the paint surface was gently cleansed using swabs slightly damp with ethanol ${ }^{66,67,68}$ (Fig.8e).

RC: A form of RB gel, but using a mixture of 1:1 Ethanol (Merck) and distilled water instead of distilled water only in RB. It was used the same way as RB application (Fig.8f).

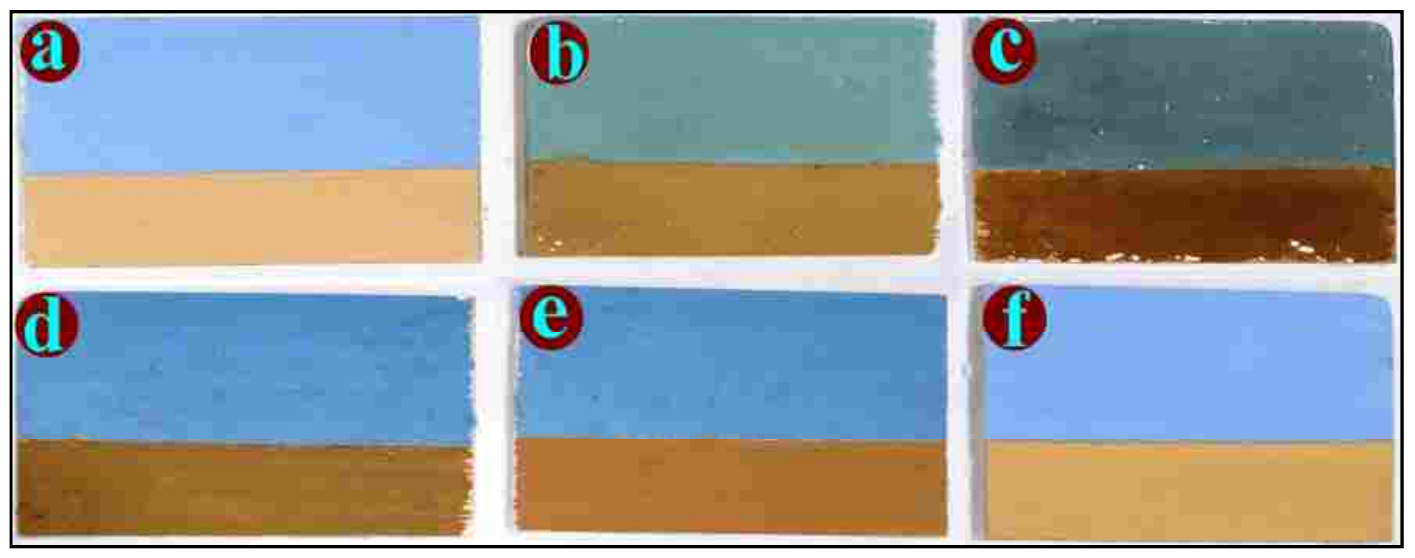

Fig. 8, The simulated samples: a. reference colored sample, b. after varnishing by polyurethane, c. after thermal aging, $d$. after varnish removal using RA, e. after varnish removal using RB, f. after varnish removal using RC.

\section{Assessment of varnish removal}

The naked eye assessment of the results revealed that the most efficient recipe was RC, while RA could not be used for this purpose, as some spots were removed but not others. Moreover, the color was still darker than the reference one. The study used the colorimeter (Optimatch 3100 Color Spectrophotometer) to assess the effects of the three recipes (RA, RB, RC) on the blue and yellow color tones to identify changes resulting from the used recipes in comparison to the reference fresh sample (not aged). The results of the used CIE $\mathrm{L}^{*}, \mathrm{a}^{*}, \mathrm{~b}^{*}$ color system was used ${ }^{69,70}$ (Table 2) revealed that $\Delta \mathrm{E}^{*}$ of RA was the highest (15.39 and 17.11) in the blue and yellow colors respectively, and $\Delta \mathrm{E}^{*}$ of $\mathrm{RC}$ was the lowest (1.38 and 1.01) in blue and yellow colors respectively. The lowest value means that the sample after varnish removal is almost similar to the reference starting sample. In other words, RC was the most efficient recipe, while RA was the worst. These results confirmed those obtained by the visual inspection.

65- Emiliano et al., A New Family of High Viscosity, J Cult Heri, 11, 4 (2010) 373-380.

66- Sutherland, The Extraction of Soluble Components, Stud in Cons, 45, (2000) 54-62.

67- Bonelli et al., Poly(vinyl alcohol)/poly(vinyl pyrrolidone), J Colloid Interf Sci, 536 (2019) 339-348.

68- Emiliano et al., A New Family of High Viscosity, J Cult Heri, 11, 4 (2010) 373-380.

69- Foster, Color Appearance, The Senses: A Comprehensive Reference, 2 (2008) 119-132.

70- Schanda, Colorimetry: Understanding the CIE System, 2007.

- 249 - $\quad$ DOI: 10.36816/shedet.006.14 
Table 2. Results of colorimetric measurements of the simulated samples

\begin{tabular}{ccccccc}
\hline & \multicolumn{2}{c}{ Blue color } & & \multicolumn{3}{c}{ Yellow color } \\
\hline & RA & RB & RC & RA & RB & RC \\
\hline$\Delta \mathrm{L}^{*}$ & -12.32 & -5.53 & -1.12 & -16.14 & -6.13 & -0.93 \\
$\Delta \mathrm{a}^{*}$ & -6.02 & 3.14 & -0.37 & 3.43 & 2.13 & 0.32 \\
$\Delta \mathrm{b}^{*}$ & -7.00 & -3.15 & -0.72 & 4.55 & 2.45 & 0.24 \\
$\Delta \mathrm{E}^{*}$ & 15.39 & 7.09 & 1.38 & 17.11 & 6.93 & 1.01 \\
\hline
\end{tabular}

\section{TREATMENT OF THE CASE STUDY PAINTING}

\section{Varnish removal and cleaning}

According to the results of varnish removal in the experimental part, the $\mathrm{RC}$ recipe was the most effective one. Therefore, it was used to remove the ancient varnish from the case study painting. The dispersion was used in a gel form. A spatula was used to apply the gel on the varnish surface. The gel was kept for 10 minutes upon the thick varnish while it was kept only 5 minutes upon the thin varnished area; the forceps were then used to carefully peel the gel layer adhering to the varnish layer. In the end, a swab slightly wet with ethanol was used to clean the little varnish residues ${ }^{71,72}$ (Fig.9). Regarding the wooden panel and frame, Toluene, acetone, and ethanol (Merck) were used in cleaning them, faults and retouching were repaired, hereafter they were varnished for future protection against environmental agents ${ }^{73,74}$ (Fig.10).
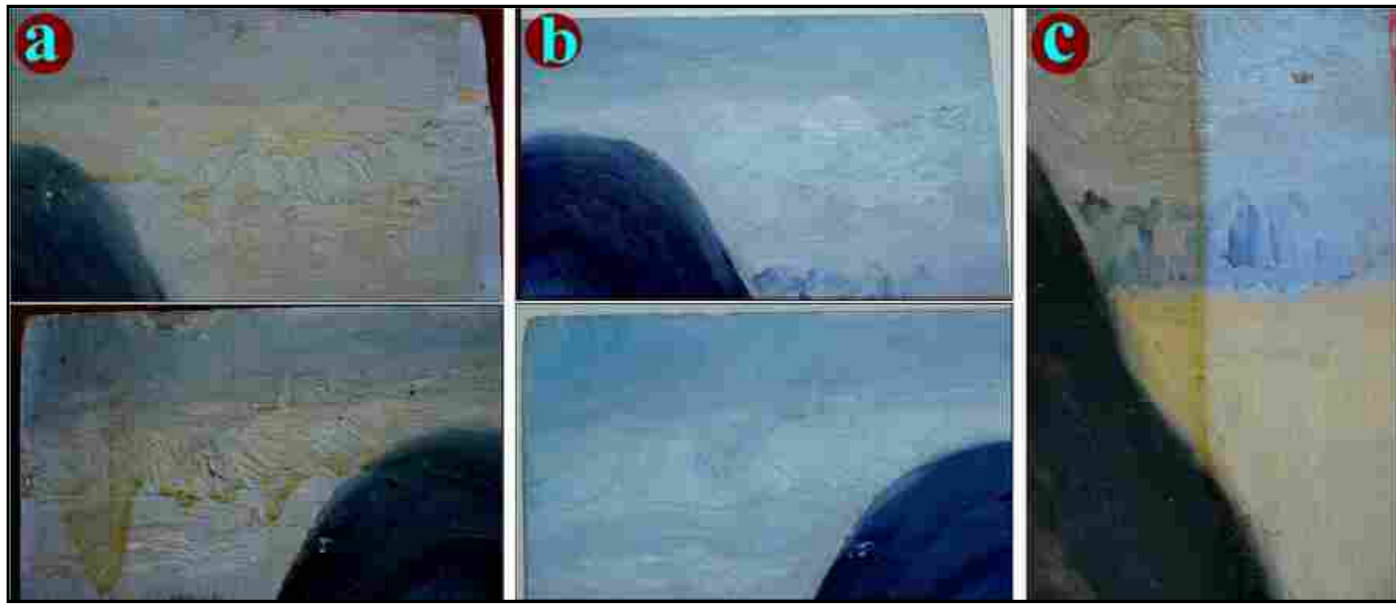

Fig.9. Varnish removal and inpainting in some areas in the case study painting; a. before varnish removal, b. after varnish removal and inpainting, c. during varnish removal.

71- Emiliano et al., A New Family of High Viscosity, J Cult Heri, 11, 4 (2010) 373-380.

72- Stulik and Miller, Research into solvent gel residues (2004) 18-65.

73- Wilmering, A Renaissance Studiolo from the Ducal Palace, Paul Getty Museum, (1995) 479-496.

74- Bret et al., The Conservation-Restoration of Wooden Painting, Paul Getty Museum, (1995) 252-263.

- 250 - Conservation Of A Historic Panel Oil-painting Coated By An Ancient Varnish Layer 


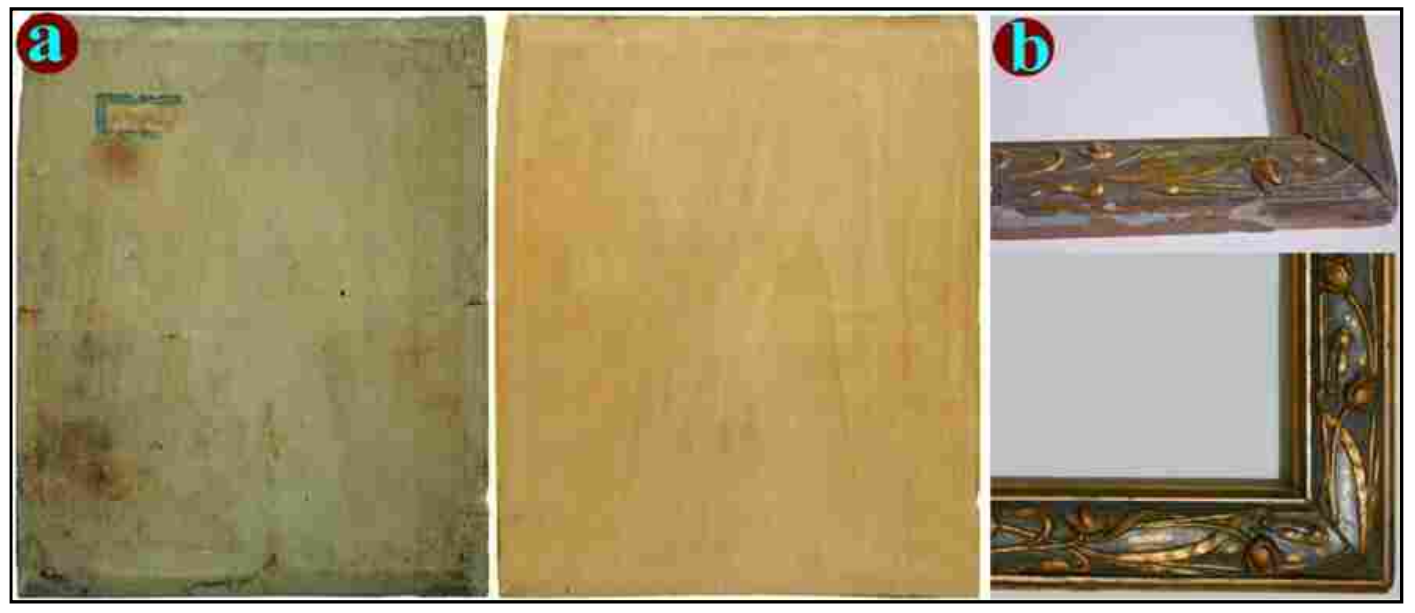

Fig.10, a. wooden panel verso before and after treatment, b. wooden frame before and after treatment.

\section{Inpainting and consolidation}

Because the case study painting suffered from many missing spots in the paint and base layer distributed in the entire object, the wooden panel appeared natural in some areas. According to the results of investigation and analysis, zinc oxide mixed with animal glue was used as a white ground layer to fill in the missing areas in the object surface. After drying for 72 hours, the Marie paint tubes (Winsor \& Newton, UK) were used for filling the missing areas in the paint layer; each tube contained the required pigment and linseed oil according to the color of the missing area (Fig.11). After drying at room temperature for an additional 72 hours, the entire surface of the case study painting was consolidated using 5\% of Beva371 (CTS) in toluene applied with a brush to fix all movable micro parts of paint and to strengthen all weak areas. ${ }^{75,76}$ Finally, the wooden frame (after cleaning and varnishing as mentioned above) was fixed using small nails upon the panel painting after finishing the treatment (Fig.12).
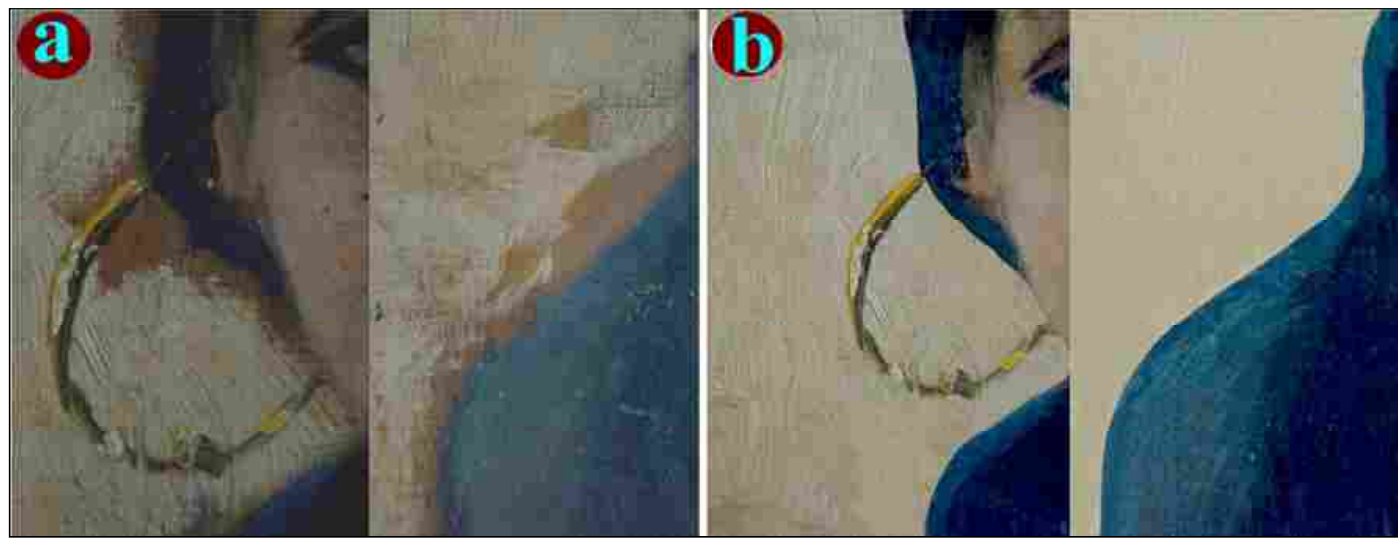

Fig.11. Inpainting of some missing spots in the object; a. before inpainting, b. after inpainting

75- Nicolaus and Christine, The Restoration of Paintings, Cologne: Könemann, 1999.

76- Stoner and Rushfield, The Conservation of Easel Paintings, Routledge, New York, 2013.

- 251 - | DOI: 10.36816/shedet.006.14 


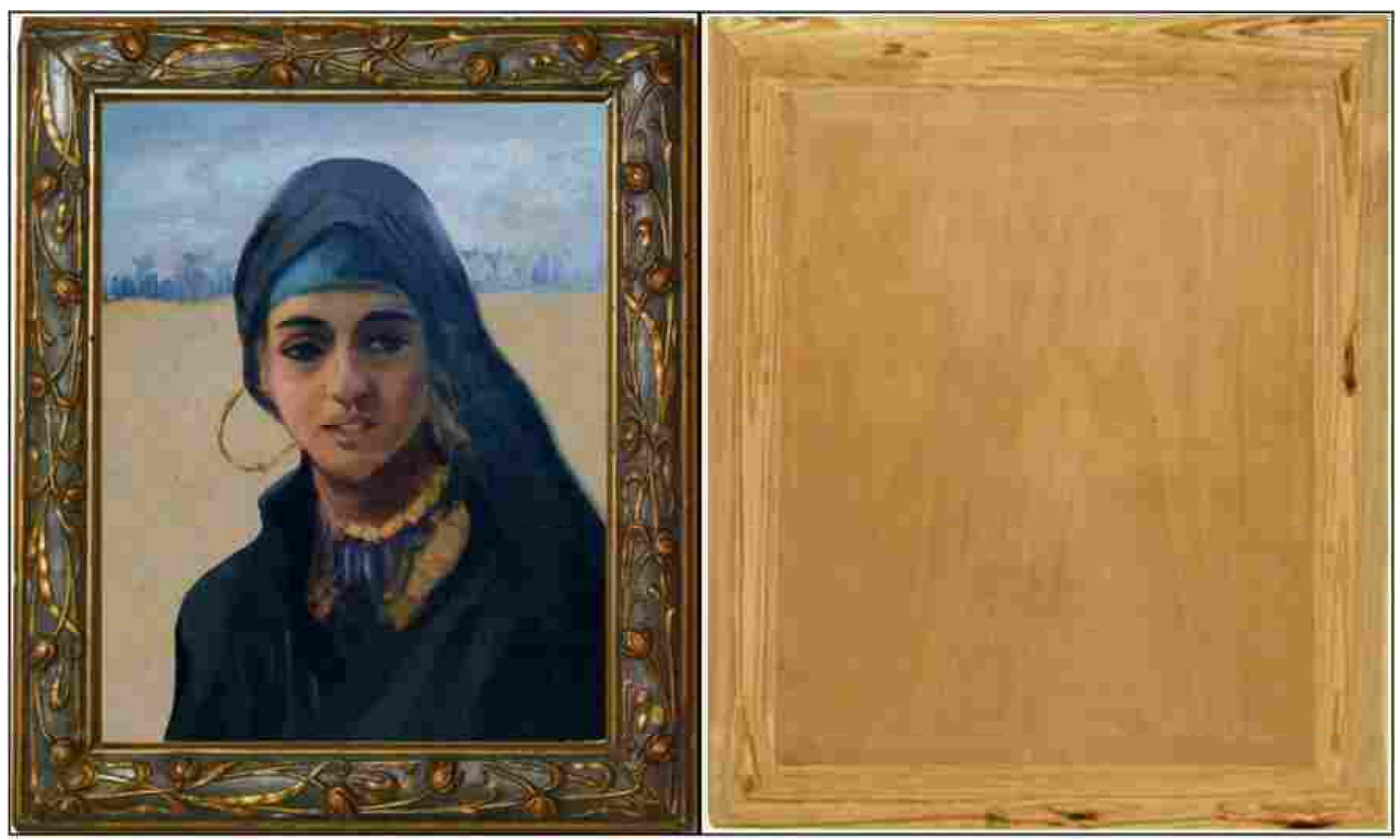

Fig.12, The case study object front and verso after treatment

\section{CONCLUSIONS}

This study looks into a deteriorated oil-painting panel, depicting a portrait named "an Egyptian peasant woman" from an anonymous painter. The main deterioration phenomenon was the ancient thick varnish layer covering the entire object, especially its upper part. Additionally, there were some missing paint areas and dark stains. The investigation and analytical techniques proved that the support panel was limewood, the white base layer consisting of both zincite and cerussite mixed with an unidentified glue. The media used was linseed oil, red pigment red ochre, yellow yellow ochre, blue cobalt blue, and black bone black. According to these results, the existing art literature, visits to art museums and the expertise of professional academics and painters, this painting was attributed to Mahmoud Sa'id (1897-1964), the most famous painter in Egypt of the early $20^{\text {th }}$ century.

Due to the thick layer of the ancient varnish covering the entire object, the study conducted some in-vitro experiments in polyurethane varnish removal from simulated panel paintings. The results revealed that the dispersion of PVAL, borax, ethanol, and water, which were used in the gel form, was the most effective formula for varnish removal from the simulated models. Consequently, it was applied to remove the ancient varnish layer form the studied object and to clean other stains. Finally, the missing paint areas were inpainted and consolidated using Beva371 5\% in Toluene.

The study recommends more focused research in the field of synthetic varnish removal, especially using diverse types of gels and innovative techniques. Despite its importance, this research field has not attracted many authors' interest. It is nevertheless an increasing problem due to the regular application of synthetic varnishes, not only in the art field, but also in the heritage conservation field. The study urgently recommends establishing a high-tech central laboratory for heritage research, to include all noninvasive investigation and analysis of heritage objects. It also recommends to issue rules that facilitate transportation of heritage objects from the museums to and from this lab

- 252 - Conservation Of A Historic Panel Oil-painting Coated By An Ancient Varnish Layer 
for investigation. This lab would greatly enrich and facilitate heritage research. Taking it abroad for non-invasive investigation and analysis in Poland was available to this case study painting because it is a private property.

\section{ACKNOWLEDGEMENTS}

The author would like to thank Mr. Janusz Czop, the deputy director of the National Museum in Kraków for the conservation and storage of collections. He extends thanks to Dr. Julio M. del Hoyo-Meléndez, the director of the Laboratory of Analysis and NonDestructive Investigation of Heritage Objects LANBOZ, National Museum in Kraków MNK for conducting the scientific imaging of the case study using VIS, UV, IR and XRay Radiography. Many thanks are due to Prof. Jerzy Łukaszewicz, the director of the Center for Modern Interdisciplinary Technologies, Nicolaus Copernicus University in Torun, Poland and Prof. Targowski Peter for the non-invasive investigation of the case study object by MA-XRF and MA-FTIR.

\section{REFERENCES}

- Abdel-Gwad, A comparative study of oil painting technology and techniques of two painters from the second Egyptian generation and its effect on the deterioration phenomena and treatment, conference and workshop on conservation, Faculty of Fine Arts, Minia University, March, 2005, pp. 123-155.

- Ajò (David), Casellato (Umberton), Fiorin (E.) and Vigat (Pietro), "Ciro Ferri's frescoes: a study of painting materials and technique by SEM-EDS microscopy, X-ray diffraction, micro FT-IR and photoluminescence spectroscopy", Journal of Cultural Heritage, 5, 4 (2004) 333-348.

- Alfeld (Matthias), De Nolfa (Wout), Cagno (Simone), Appel (Karen), Peter (Siddons), Kuczewski, (Anthony), Janssens (Koen), Dik (Joris), Trentelman (Karen), Walton (Marc) and Sartorius (Andrea), "Revealing hidden paint layers in oil paintings by means of scanning macro-XRF: a mock-up study based on Rembrandt's "Old man in military costume", Journal of Analytical Atomic Spectrometry, 28, 1 (2013) 28-40.

- Alfeld (Matthias), Janssens (Koen), Dik (Joris), De Nolfa (Wout), Van der Snickt (Geert), "Optimization of mobile scanning macro-XRF systems for the in situ investigation of historical paintings", Journal of Analytical Atomic Spectrometry, 26 (2011) 899-909.

- Barnett,( J. R.), Sarah (Miller), Emma (Pearce), "Colour and art: a brief history of pigment", Optic \& Laser Technology, 38 (2005) 445-453.

- Bonelli (Nicole), Poggi (Giovanna), Chelazzi (David), Giorgi (Rodorico), Baglioni (Piero), "Poly(vinyl alcohol)/poly(vinyl pyrrolidone) hydrogels for the cleaning of art", Journal of Colloid and Interface Science, 536 (2019) 339-348.

- Bret (Jacqueline), Jaunard (Daniel) and Mandron (Patrick), “The Conservation-Restoration of Wooden Painting Supports", in Dardes K. and Rothe A. (eds), The Structural Conservation of Panel Paintings, proceedings of a symposium at the J. Paul Getty Museum, 24-28 April, Los Angles (1995) 252-263.

- Burnstock (Aviva) and Learner (Tom), "Changes in the Surface Characteristics of Artificially Aged Mastic Varnishes After Cleaning Using Alkaline Reagents", Studies in Conservation, 37, 3 (1992) 165-184.Campos (P.), Kajiya (Elizabeth), Rizzutto (Marcia), Neiva (Augusto), Pinto (Herbert) Almeida (Paula), "X-ray fluorescence and imaging analyses of paintings by the Brazilian artist Oscar Pereira Da Silva", Radiation Physics and Chemistry, 95 (2014) 362-367.

- 253 - DOI: $10.36816 /$ shedet.006.14 
- Carretti (Emiliano), Dei (Luigi), Weiss (Richard) and Baglioni (Piero), "A new class of gels for the conservation of painted surfaces", Journal of Cultural Heritage, 9 (2008) 386-393.

- Clark (Robin), "Pigment Identification by Spectroscopic Means: an Arts/Science Interface", Comptes Rendus - Chimie, 5, 1 (2002) 7-20.

- Costa (Thiago), Ritcher (Fabio), Correia (Marcelino), Escorteganha (Márcia), Santiago (Alina), Gonçalves (Samantha), Spudeit (Daniel), Micke (Gustavo) and Miranda (Fábio), "Multi-Technical Analysis As a Tool to Investigate Structural Species in the 'replica' of First Mass in Brazil Painting by Sebastião Vieira Fernandes", Journal of Molecular Structure, 1120 (2016) 196-204.

- Cucci (Costanza), Picollo (Marcello), Vervat (Muriel), "Trans-illumination and transirradiation with digital cameras: Potentials and limits of two imaging techniques used for the diagnostic investigation of paintings", Journal of Cultural Heritage, 13 (2012) 83-88.

- Daveri (Alessia), Malagodi (Marco) and Vagnini (Manuela), "The Bone Black Pigment Identification by Noninvasive, In Situ Infrared Reflection Spectroscopy", Journal of Analytical Methods in Chemistry, 8 (2018) 1-8.

- De Keyser (Nouchka), Van der Snickt (Geert), Loon (Van), Legrand (Stijn), Walton (Marc), Janssens, (Koen), "Jan Davidsz. de Heem (1606-1684): a technical examination of fruit and flower still lifes combining MA-XRF scanning, cross-section analysis and technical historical sources", Heritage Science (2017) 5:38.

- De viguerie (Laurence), Walter (Philippe), Laval (Eric), Mottin (Bruno) and Solé (Armando), "Revealing the sfumato technique of Leonardo da Vinci by X-Ray Fluorescence Spectroscopy”, Angewandte Chemie International Edition, 49, 35 (2010) 6125-6128.

- Defeyt (Catherine), Langenbacher (Julia) and Rivenc (Rachel), "Polyurethane coatings used in twentieth century outdoor painted sculptures. Part I: comparative study of various systems by means of ATR-FTIR spectroscopy", Heritage Science (2017) 5:11.

- Delaney (John) Zeibel (Jason) Thoury (Mathieu) Littleton (Roy) Palmer (Michael) Morales (Kathryn) de la Rie (René) and Hoenigswald (Ann), "Visible and Infrared Imaging Spectroscopy of Picasso's Harlequin Musician: Mapping and Identification of Artist Materials in Situ", Applied Spectroscopy, 64, 6 (2010) 584-594.

- Elsayed (Yosr) and Shabana (Yasser), "The Effect of Some Essential Oils on Aspergillus Niger and Alternaria Alternata Infestation in Archaeological Oil Paintings", Mediterranean Archaeology and Archaeometry, 18, 3 (2018) 71-87.

- Elsayed (Yosr), "Identification of Oil Media in Five Canvas Paintings at The Agricultural Museum in Egypt", Journal of Faculty of Archaeology (Qena), 10 (2015) 60-92.

- Emandi (Ioan), Mihai (Iovea), Octavian (Duliu), and Ana (Emandi), "X-Ray Radiographic Study of some Panel Painting Icons from the Beginning of the XX Century", International Journal of Conservation Science, 2,3 (2011) 179-183.

- Emiliano (Carretti), Natali (Irene), Matarrese (Caterina), Bracco (Paola), Weiss (Richard), Baglioni (Piero), Salvini (Antonella) and Dei (Luigi), "A New Family of High Viscosity Polymeric Dispersions for Cleaning Easel Paintings", Journal of Cultural Heritage, 11, 4 (2010) 373-380.

- Ferri (Dott.ssa), "OM - SEM/EDS - $\mu$ FT -IR Synergy Rapid Palette Identification of Paintings Cross-Sections", Imaging \& Microscopy, 24 (2015).

- Foster (David), "Color Appearance", in Basbaum A. I., Kaneko A., Shepherd G. M., Westheimer G., Albright T. D. and Masland R. (eds.), The Senses: A Comprehensive Reference, 2 (2008) 119-132.

- 254 - $\mid$ Conservation Of A Historic Panel Oil-painting Coated By An Ancient Varnish Layer 
- Galatis (Panagiotis), Boyatzis (Stamatis) and Theodorakopoulos (Charis), "An Investigation of the Selective Removal Of a Synthetic Soiling Mixture From Mastic, Shellac \& Laropal ${ }^{\circledR}$ K80 Coatings Using Hydrogels", e-Preservation Science, 9 (2012) 72-8.

- Genestar (Catalina) and Pons (Carmen), "Earth pigments in painting: characterisation and differentiation by means of FTIR spectroscopy and SEM-EDS microanalysis", Analytical and Bioanalytical Chemistry, 382 (2005) 269-274.

- Helmi (Fatma) and Abdel-Gwad (Mostafa), Scientific Study For Restoration and Conservation of Oil Paintings, Elamal Publisher, Cairo, 1992.

- Helwing (Kate), "Iron oxide pigments, natural and synthetic", In Berrie, B. H. (ed.), Artists Pigments: A Handbook of Their History and Characteristics, National Gallery of Art, Washington, 4 (2007) 39-109.

- Hoadley (Bruce), "Identification of Wood in Painting Panels, The structural conservation of panel paintings" in Dardes K. and Rothe A. (eds), The Structural Conservation of Panel Paintings, proceedings of a symposium at the J. Paul Getty Museum, 24-28 April, Los Angles (1995) 21-38.

- Hook (John), "The Use of Immiscible Solvent Combinations for the Cleaning of Paintings", Journal of the American Institute for Conservation, 27, 2 (1988) 100-104.

- Kopecká (Ivana) and Svobodová (Eva), "Methodology for infrared spectroscopy analysis of sandwich multilayer samples of historical materials", Heritage Science, 2, 22, 2014.

- Marín (Eva) and Garcia (Jose), "The sixteenth century panel Virgin with the Child and an Angel, confluences of material characterization and iconography", Journal of Cultural Heritage, 29 (2018) pp. 160-167.

- Miliani (Costanza), Rosi (Francesca) and Giovanni (Brunetti), "Reflection infrared spectroscopy for the non-invasive in situ study of artists' pigments", Applied Physics A: Materials Science and Processing, 106 (2012) 295-307.

- Miliani (Costanza), Rosi (Francesca), Giovanni (Brunetti) and Sgamellotti (Antonio), "In situ noninvasive study of artworks: the MOLAB multitechnique approach", Accounts of Chemical Research, 43, 6 (2010) 728-738.

- Nicolaus (Knut) and Christine (Westphal), The Restoration of Paintings, Cologne: Könemann, 1999.

- Phenix (Alan), "The Swelling of Artist's Paints in Organic Solvents: Part 1: a Simple Method for Measuring the in-Plane Swelling of Unsupported Paint Films" Journal of the American Institute for Conservation, 41 (2002) 43-60.

- Popescu (C.-M), Tibirna (Carmen), Manoliu (A.), Petronela (Gradinariu) and Vasile (Cornelia), "Microscopic study of lime wood decayed by chaetomium globosum", Cellulose Chemistry and Technology, 45 (2011) 565-569.

- Robinet (Laurianne) and Marie-Claude (Corbeil), "The Characterization of Metal Soaps", Studies in Conservation, 48 (2003) 23-40.

- Samoilescu (Dorina), Duliu (Octavian), Manea (Maria), Stan (Daniela), Constantinescu (Bogdan), "A comparative study of two icons representing the "Coronation of the Virgin by the Holy Trinity' Walachia, $18^{\text {th }}$ century and Transylvania, $19^{\text {th }}$ century" Journal of Cultural Heritage, 27 (2017) pp. 175-180.

- Schanda (János), Colorimetry: Understanding the CIE System, Hoboken, N.J: Wiley, 2007.

- Šefců (Radka), Chlumská (Štěpánka), Třeštíková (Anna), Trojek (Tomáš) and Dragounová (Lenka), "Investigation of the panel painting of St Anne with the Virgin Mary and the Child Jesus using analytical and imaging methods", Applied Radiation and Isotopes, 95 (2015) 812.

- Shabunya-Klyachkovskaya (Elena), Kulakovich (Olga), Mitskevich (Anagelika), Moiseev (Yuri), Kiris (Vasilis), Matsukovich (Anna), Karoza (Anatolii), Sysoeva (Liubou) and

- 255 - $\quad$ DOI: $10.36816 /$ shedet.006.14 
Belkov (Mikhail), "A Multi-Analytical Study of the Belarusian Icon 'virgin Eleusa' (xvii Cent.)", Journal of Cultural Heritage, 28 (2017) 158-163.

- Silva (Eduardo), Silva (Luciana), Edwards (Howell), de Oliveira (Luiz), "Diffuse reflection FTIR spectral database of dyes and pigments", Analytical and Bioanalytical Chemistry, 386 (2006) 2183-2191.

- Spring (Marika), Kugler (Veronika) and Bean (Stewart), "Quantitative energy dispersive Xray analysis of the blue pigment smalt in the variable pressure scanning electron microscope", In Meeks N., Cartwright C., Meek A., Mongiatti A. (eds), Historical technology, materials and conservation: SEM and microanalysis, Archetype Publications in association with the British Museum, London, 2012.

- Stoner (Joyce) and Rushfield (Rebecca), The Conservation of Easel Paintings, Routledge, New York, 2013.

- Stulik (Dusan), Miller (David), "Research into solvent gel residues", in Stulik D., Miller D., Khanjian H. and Dorge V. (eds), Solvent Gels for the Cleaning of Works of Art: the Residue Question, Los Angeles, Calif: J. Paul Getty Trust, 2004, 18-65.

- Sutherland (Ken), "The Extraction of Soluble Components from an Oil Paint Film by a Varnish Solution", Studies in Conservation, 45, 1 (2000) 54-62

- Targowski (Piotr), Pronobis-Gajdzis (Małgorzata), Surmak (Aleksandra), Iwanicka (Magdalena), Kaszewska (Ewa) and Sylwestrzak (Marcin), "The Application of Macro-XRay Fluorescence and Optical Coherence Tomography for Examination of Parchment Manuscripts", Studies in Conservation, 60 (2015) 167-177.

- Vahur (Signe), Teearu (Anu), Peets (Pilleriin), Joosu (Lauri) and Leito (Ivo), "TR-FT-IR spectral collection of conservation materials in the extended region of $4000-80 \mathrm{~cm}^{-1}$, Analytical and Bioanalytical Chemistry, 408 (2016) 3373-3379.

- Véliz (Zahira), "Wooden Panels and Their Preparation for Painting from the Middle Ages to the Seventeenth Century in Spain", in Dardes K. and Rothe A. (eds), The Structural Conservation of Panel Paintings, proceedings of a symposium at the J. Paul Getty Museum, 24-28 April, Los Angles (1995) 136-148.

- Wadum (Jørgen), "Historical Overview of Panel-Making Techniques in the Northern Countries", in Dardes K. and Rothe A. (eds), The Structural Conservation of Panel Paintings, proceedings of a symposium at the J. Paul Getty Museum, 24-28 April, Los Angles (1995) 149-177.

- Wilmering (Antoine), "A Renaissance Studiolo from the Ducal Palace in Gubbio Technical Aspects of the Conservation Treatment", in Dardes K. and Rothe A. (eds), The Structural Conservation of Panel Paintings, proceedings of a symposium at the J. Paul Getty Museum, 24-28 April, Los Angles (1995) 479-496.

- Winter (J.) and Fitzhugh (West), "Pigments based on carbon", in Feller R. (ed.), artist's pigments, a handbook of their history and characteristics, National Gallery of Art, London, Archetype Publications, (2007).

- Wolbers (Richard), Cleaning Painted Surfaces: Aqueous Methods, Archetype Publications, London, 2003.

- Yongxiang (Xu), Chuanwei (Yan), Jie (Ding), Yanmin (Gao), Chunan (Cao), "Water vapour in the coatings of alkyd and polyurethane varnish", Progress in Organic Coatings, 45, 4 (2002) 331-339.

- 256 - $\mid$ Conservation Of A Historic Panel Oil-painting Coated By An Ancient Varnish Layer 